\title{
A molecular phylogenetic appraisal of the acanthostomines Acanthostomum and Timoniella and their position within Cryptogonimidae (Trematoda: Opisthorchioidea)
}

\author{
Andres Martínez Aquino ${ }^{\text {Corresp.. }}{ }^{1}$, Victor M Vidal-Martinez ${ }^{1}$, Leopoldina Aguirre-Macedo ${ }^{\text {Corresp. } 1}$ \\ 1 Departamento de Recursos del Mar, Centro de Investigación y de Estudios Avanzados del Instituto Politécnico Nacional, Unidad Merida, Merida, Yucatan, \\ Mexico \\ Corresponding Authors: Andres Martínez Aquino, Leopoldina Aguirre-Macedo \\ Email address: maandres_@hotmail.com, leopoldina.aguirre@cinvestav.mx
}

The phylogenetic position of three taxa from two trematode genera, belonging to the subfamily Acanthostominae (Opisthorchioidea: Cryptogonimidae), were analysed using partial 28S ribosomal DNA (Domains 1-2) and internal transcribed spacers (ITS1-5.8S-ITS2). Bayesian inference and Maximum likelihood analyses of combined 28S rDNA and ITS1 + 5.8S + ITS2 sequences indicated the monophyly of the genus Acanthostomum (A. cf. americanum and A. burminis) and paraphyly of the Acanthostominae. These phylogenetic relationships were consistent in analyses of $28 \mathrm{~S}$ alone and concatenated 28S + ITS1 + 5.8S + ITS2 sequences analyses. Based on molecular phylogenetic analyses, the subfamily Acanthostominae is therefore a paraphyletic taxon, in contrast with previous classifications based on morphological data. Phylogenetic patterns of host specificity inferred from adult stages of other cryptogonimid taxa are also well supported. However, analyses using additional genera and species are necessary to support the phylogenetic inferences from this study. Our molecular phylogenetic reconstruction linked two larval stages of $A$. cf. americanum cercariae and metacercariae. Here, we present the evolutionary and ecological implications of parasitic infections in freshwater and brackish environments. 
1 A molecular phylogenetic appraisal of the acanthostomines Acanthostomum and Timoniella

2 and their position within Cryptogonimidae (Trematoda: Opisthorchioidea)

3

4 Andrés Martínez-Aquino, Víctor M. Vidal-Martínez, M. Leopoldina Aguirre-Macedo*

5

6 Laboratorio de Patología Acuática, Departamento de Recursos del Mar, Centro de Investigación

7 y de Estudios Avanzados del Instituto Politécnico Nacional, Unidad Mérida, Cordemex,

8 Carretera Antigua a Progreso Km. 6, Mérida, Yucatán, 97310, México

9

$10 *$ Corresponding author: leopoldina.aguirre@cinvestav.mx

11

12 


\section{Abstract}

14 The phylogenetic position of three taxa from two trematode genera, belonging to the subfamily

15 Acanthostominae (Opisthorchioidea: Cryptogonimidae), were analysed using partial 28S

16 ribosomal DNA (Domains 1-2) and internal transcribed spacers (ITS1-5.8S-ITS2). Bayesian

17 inference and Maximum likelihood analyses of combined 28S rDNA and ITS1 + 5.8S + ITS2

18 sequences indicated the monophyly of the genus Acanthostomum (A. cf. americanum and $A$.

19 burminis) and paraphyly of the Acanthostominae. These phylogenetic relationships were

20 consistent in analyses of 28S alone and concatenated 28S + ITS1 + 5.8S + ITS2 sequences

21 analyses. Based on molecular phylogenetic analyses, the subfamily Acanthostominae is therefore

22 a paraphyletic taxon, in contrast with previous classifications based on morphological data.

23 Phylogenetic patterns of host specificity inferred from adult stages of other cryptogonimid taxa

24 are also well supported. However, analyses using additional genera and species are necessary to

25 support the phylogenetic inferences from this study. Our molecular phylogenetic reconstruction

26 linked two larval stages of $A$. cf. americanum cercariae and metacercariae. Here, we present the

27 evolutionary and ecological implications of parasitic infections in freshwater and brackish

28 environments. 


\section{Introduction}

31 The Cryptogonimidae Ward, 1917, is a speciose family ( $\geq 370$ species), consisting of 93 genera

32 associated with the intestine or pyloric caeca of marine and freshwater teleosts, reptiles and

33 occasionally amphibians around the world (Miller and Cribb 2008a, 2013; Miller et al. 2009,

34 2010a, b; Cribb and Gibson 2010; Tkach and Bush 2010; Fernandes et al. 2013). Since

35 taxonomic identification based on morphological characters is complex (i.e., it is based on

36 combinations of characters), the taxonomic classification of species within Cryptogonimidae

37 (e.g., at the subfamily level) has been reworked several times (Miller and Cribb 2008a).

38 Taxonomic schemes of subfamilies can also be detected based on ecological factors and host

39 preferences. For example, studies based on phylogenetic approaches infer hierarchical-

40 taxonomic patterns between cryptogonimid species associated with specific marine fish hosts

41 (e.g., Retrovarium spp. that are associated with perciform marine fishes), or cryptogonimid

42 genera associated with reptile taxa (e.g., the subfamily Acanthostominae Looss, 1899) (Brooks

43 1980; Miller and Cribb 2007a, 2008a). In particular, the Acanthostominae was inferred based on

44 morphology, phylogeny and biogeographical and host-parasite association patterns (Brooks

45 1980; Brooks and Holcman 1993). The criteria for the subfamily Acanthostominae, as

46 recognized by Brook and Holcman (1993), was based on six characters: 1) a terminal oral

47 sucker; 2) a body armed with single row of spines; 3) a preacetabular pit; 4) a genital pore not in

48 preacetabular pit; 5) a seminal vesicle coiled posteriorly; and 6) a sucker-like gonotyl. Based on

49 these criteria, the acanthostomine trematodes include five genera: Timoniella Rebecq, 1960;

50 Proctocaecum Baught, 1957; Gymnatrema Morozov, 1955; Caimanicola Freitas and Lent, 1938;

51 and Acanthostomum Looss, 1899 (Brooks 2004). Nevertheless, Miller and Cribb (2008a) were

52 not convinced by the morphological characteristics that were used to justify subfamily-level 
53 divisions in Cryptogonimidae, because several subfamilies were separated by few, and often

54 trivial, characters. Miller and Cribb (2008a) also recognized that the phylogenetic analyses of

55 acanthostomines by Brooks (1980) could be used to infer intergeneric relationships between

56 cryptogonimids.

57 To explore the diversity of helminth parasite fauna from aquatic invertebrate and

58 vertebrate hosts in Mexico (Vidal-Martínez et al. 2001; Aguirre-Macedo et al. 2017), molecular

59 phylogenetic analyses based on nuclear gene fragments (partial 28S ribosomal DNA and the

60 internal transcribed spacers (ITS1-5.8S-ITS2)) were carried out on cryptogonomids from

61 Mexico’s Yucatán Peninsula. The analyses were used to answer questions regarding the

62 phylogenetic position of acanthostomines within the family Cryptogonomidae, and possible life-

63 cycle links between cercariae and metacercariae were additionally examined. Based on the

64 results of the molecular phylogenetic analyses, the systematic position of the acanthostomine

65 genera Acanthosthomum and Timoniella were evaluated, with a brief discussion of the taxonomic

66 implications for the subfamily Acanthostominae, and phylogenetic evidence to support the

67 different intergeneric relationships among Cryptogonimidae is provided.

68 Material and methods

69 Collection of hosts and trematode parasites

70 As part of our ongoing study in the Celestun Lagoon (Sosa-Medina et al. 2015), we collected

71 specimens of cryptogonimid metacercariae presumed to be of the subfamily Acanthostominae:

72 Acanthostomum americanum (= Atrophecaecum astorquii) Pérez-Vigueras, 1956, and

73 Timoniella (= Pelaezia) loossi Pérez-Vigueras, 1956, from the Ria Celestun Biosphere Reserve,

74 Yucatan Peninsula, Mexico (based on Moravec 2001; Vidal-Martínez et al. 2001; Brooks 2004;

75 Miller and Cribb 2008a). These metacercariae were collected from the euryhaline fish 
76 Cichlasoma urophthalmus (Günter, 1862) (Perciformes: Cichlidae) from the Yaxaá water spring

$77\left(20^{\circ} 53^{\prime} 12.57^{\prime} \mathrm{N}\right.$; $\left.90^{\circ} 20^{\prime} 58.86^{\prime \prime} \mathrm{W}\right)$, located in the Celestun tropical lagoon (Fig. 1). We also

78 collected cercariae presumed to be of the Cryptogonimidae from the aquatic gastropod

79 Pyrgophorus coronatus (Pfeiffer, 1840) (Hybrobiidae) (see Scholz et al. 2000), at the same

80 location, to test for possible life-cycle links between the cercariae and metacercariae with

81 molecular data. In March 2016 we collected 223 snails of $P$. coronatus from two localities:

82 Baldiocera Spring (2054’6.29” N; 90²0’26.46” W) (156 snails) and Yaxaá Spring (67

83 snails) (the two springs are approximately 1,400 metres apart). Snails were collected using

84 strainers, placed separately into glass tubes and maintained in artificial light in the laboratory to

85 stimulate the emergence of cercariae. After 2-3 days, portions of the snails were removed from

86 their shells by dissection under a stereomicroscope. The only representatives of Cyptogonimidae

87 (3 cercariae) were collected from a single $P$. coronatus from Yaxaá Spring. For representatives

88 of other families, of the 156 P. coronatus examined from Baldiocera Spring, we observed two

89 cercaria of Ascocotyle (Phagicola) nana Ransom, 1920 (Heterophyidae) in each of two

90 individual snails; and one metacercaria of Crassicutis cichlasomae Manter, 1936

91 (Apocreadiidae) from one snail. Both larvae have been previously recorded from P. coronatus

92 (Scholz et al. 2000). Of the 67 P. coronatus examined from Yaxaá Spring, the only cercariae

93 observed belonged to the aforementioned cryptogonimids. We also sampled specimens of other

94 adult cryptogonimids, e.g., Oligogonotylus mayae Razo-Mendivil et al. 2008, from the cichlid

95 fish C. urophthalmus. The protocols for host dissection, examination, collection and preservation,

96 and the morphological study of parasitic specimens followed Vidal-Martínez et al. (2001). We

97 also collected adult specimens of the apocreadiid species Crassicutis cichlasomae, from the same

98 fish host. Crassicutis cichlasomae was used as an outgroup taxon for the phylogenetic analyses 
99 in this study, based on its previously established sister group relationship of Ophisthorchioidae

100 (Bray et al. 2009; Fraija-Fernández et al. 2015). Trematodes were identified based on

101 morphological criteria suggested by Vidal-Martínez et al. (2001), Miller and Cribb (2008a) and

102 Razo-Mendivil et al. (2008, 2010). Reliable identification to genus level is possible for both

103 Timoniella and Acanthosthomum based on metacercariae morphology. Microphotographs of both

104 taxa can be found in Supplementary information Fig. S1. However, identification to species level

105 may be questionable, therefore we hereafter refer to the species as $T$. cf. loossi and $A$. cf.

106 americanum. Several metacercariae and adult specimens collected for morphological analysis

107 were deposited as voucher specimens [T. cf. loossi (No. 525), A. cf. americanum (No. 526), $C$.

108 cichlasomae (No. 527) and O. mayae (No. 528)] in the Colección Helmintológica del

109 CINVESTAV (CHCM), Departamento de Recursos del Mar, Centro de Investigación y de

110 Estudios Avanzados del Instituto Politécnico Nacional, Unidad Mérida, Yucatán, México.

111 Acanthostomine cercariae were not deposited because each specimen was required for the

112 molecular study. Comisión Nacional de Acuacultura y Pesca (PPF/DGOPA-070/16) issued the

113 collecting permits.

\section{DNA extraction, PCR amplification and sequencing}

115 DNA was extracted from individual cercariae, metacercariae and adult trematodes. DNA

116 extraction was performed using the DNAeasy blood and tissue extraction kit (Qiagen, Valencia,

117 CA, USA) following the manufacturer's instructions. For the four trematode taxa, the partial $28 \mathrm{~S}$

118 ribosomal gene region was amplified by Polymerase Chain Reaction (PCR) (Saiki 1988), using

119 28sl forward (5'-AAC AGT GCG TGA AAC CGC TC- 3') (Palumbi et al. 1996) and LO reverse

120 (5'-GCT ATC CTG AG(AG) GAA ACT TCG- 3') (Tkach et al. 2000). The primers BD1

121 forward (5' -GTC GTA ACA AGG TTT CCG TA- 3') and BD2 reverse (5'-TAT GCT TAA 
122 ATT CAG CGG GT-3') (Bowles et al. 1995) were used for ITS1-5.8S-ITS2 fragment. The

123 reactions were prepared using the Green GoTaq Master Mix (Promega). This procedure was

124 carried out using an Axygen Maxygen thermocycler. PCR cycling conditions by both molecular

125 markers were as follows: an initial denaturing step of 5 min at $94{ }^{\circ} \mathrm{C}$, followed by 35 cycles of

$12692{ }^{\circ} \mathrm{C}$ for $30 \mathrm{~s}, 55^{\circ} \mathrm{C}$ for $45 \mathrm{~s}$, and $72{ }^{\circ} \mathrm{C}$ for $90 \mathrm{~s}$, and a final extension step at $72{ }^{\circ} \mathrm{C}$ for $10 \mathrm{~min}$.

127 The PCR products were analysed by electrophoresis in 1\% agarose gel using TAE $1 \mathrm{X}$ buffer and 128 observed under UV light using the QIAxcel®Advanced System. The purification and sequencing

129 of the PCR products were carried out by Genewiz, South Plainfield, NJ, USA

130 (https://www.genewiz.com/).

\section{Molecular data and phylogenetic reconstruction}

132 To obtain the consensus sequences of the larvae and adults of $A$. cf. americanum, T. cf. loossi, O.

133 mayae and C. cichlasomae, we assembled and edited the chromatograms of forward and reverse

134 sequences using the Geneious Pro v5.1.7 platform (Drummond et al. 2010). To investigate the

135 monophyly of the taxa included in Cryptogonimidae at the subfamily level, the 28S, ITS1, 5.8S

136 and ITS2 sequences that were generated during this study were aligned with sequences of other

137 cryptogonimids, and their sister groups, heterophyid and opisthorchiid taxa (based on

138 Thaenkham et al. 2011, 2012), obtained from GenBank (see GenBank accession numbers in

139 Supplementary Table S1), using an interface available with MAFFT v.7.263 (Katoh and

140 Standley 2016), an "auto" strategy and a gap-opening penalty of 1.53 with Geneious Pro, and a

141 final edition by eye in the same platform. The best partitioning scheme and substitution model

142 for each molecular marker was selected by using the "greedy" search strategy in Partition Finder

143 v.1.1.1 (Lanfear et al. 2011, 2014) and applying the Bayesian Information Criterion (BIC)

144 (Schwarz 1978). The nucleotide substitution model that best fit the $28 \mathrm{~S}$ data was TVM $+\mathrm{I}+\mathrm{G}$ 
145 (Posada 2003); for ITS1 and ITS2 it was TVMef $+\mathrm{G}$ (Posada 2003); and for 5.8S, it was JC + G

146 (Jukes and Cantor 1969). Hypervariable regions of 28S, ITS1 and ITS2 alignments were

147 excluded using the Gblocks Web Server (Castresana 2000; Talavera and Castresana 2007).

The datasets were analysed by Bayesian inference (BI) and Maximum likelihood analyses

149 (ML) using the CIPRES Science Gateway v. 3.3 (Miller et al. 2010). ML analyses were

150 conducted in RaxML v. 8 (Stamatakis 2014) using the GTRCAT approximation as a model of

151

152

153

154

155

156

157

158

159

160

161

162

163

164 165 166

nucleotide substitution (Yang 1994, 1996; Stamatakis 2006). BI analyses were carried out with MrBayes v. 3.2.1 (Ronquist et al. 2012). The Bayesian phylogenetic trees were reconstructed for each gene separately using two parallel analyses of Metropolis-Coupled Markov Chain Monte Carlo (MCMC) for $20 \times 10^{6}$ generations each. Topologies were sampled every 1,000 generations and the average standard deviation of split frequencies was observed until it reached $<0.01$, as suggested by Ronquist et al. (2012). A majority consensus tree with branch lengths was reconstructed for the two runs after discarding the first 5,000 sampled trees. For both ML and BI analyses, model parameters were independently optimized for each partition. Node support was evaluated by non-parametric bootstrapping (Felsenstein 1985) with 1,000 replicates performed with RAxML (ML) and BI by Posterior probabilities (PP), where bootstrap values $\geq 75 \%$ and PP $\geq 0.95$, were considered strongly supported.

\section{Results}

\section{DNA sequences and dataset analyses}

In total, 36 bi-directional partial 28S (domains 1 and 2) and ITS1-5.8S-ITS2 sequences were obtained from three individual cercariae and three individual metacercariae from $A$. cf. americanum, as well as three individual metacercariae from $T$. cf. loossi, O. mayae (one adult 
167 specimen), and C. cichlasomae (one adult specimen, outgroup) (Table 1). The partial 28S rDNA

168 sequence fragment consisted of 881 base-pairs (bp) for the cercariae and metacercariae of $A$. cf.

169 americanum; $880 \mathrm{bp}$ in T. cf. loossi, 871 bp in $O$. mayae, and $870 \mathrm{bp}$ in C. cichlasomae. The $28 \mathrm{~S}$

170 sequences of cercariae and metacercariae of $A$. cf. americanum from P. coronatus were identical,

171 while the sequences of $T$. cf. loossi showed a divergence of $0.03 \%$. Nucleotide sequence

172 variation in the $28 \mathrm{~S}$ alignment from cryptogonimids (excluding the outgroup taxon) from $28 \mathrm{~S}$

173 included 722 conserved sites, 537 variable sites, 403 parsimony-informative sites, and 134

174 singleton sites. The sequence fragments for the ITS1 nuclear marker were between 709 and 781

$175 \mathrm{bp}$ in length for $A$. cf. americanum; and were $805 \mathrm{bp}$ in T. cf. loossi, $613 \mathrm{bp}$ in O. mayae, and 424

$176 \mathrm{bp}$ in C. cichlasomae. The $5.8 \mathrm{~S}$ nuclear marker was composed of $160 \mathrm{bp}$ in A. cf. americanum, $T$.

177 cf. loossi, O. mayae and C. cichlasomae. The length of the ITS2 nuclear marker ranged from 259

178 bp to $277 \mathrm{bp}$ in $A$. cf. americanum and from $268 \mathrm{bp}$ to $277 \mathrm{bp}$ in $T$. cf. loossi; $260 \mathrm{bp}$ in O. mayae,

179 and $295 \mathrm{bp}$ in C. cichlasomae. The ITS1 and ITS2 sequences of $A$. cf. americanum displayed 4\%

180 and $0.7 \%$ divergence, respectively, and those from $T$. cf. loossi displayed $0.9 \%$ divergence and

$181100 \%$ pairwise identity; the $5.8 \mathrm{~S}$ sequences were identical. Nucleotide sequence variation

182 (excluding the outgroup taxa) for ITS1, 5.8S and ITS2 were 62/69/50 conserved, 406/92/212

183 variable, 341/36/184 parsimony-informative, and 65/56/28 singleton sites, respectively.

184 Phylogenetic reconstructions

185 We inferred the phylogenetic relationships of Cryptogonimidae, based on the BI and ML

186 analyses, from the following two datasets. The partial $28 \mathrm{~S}$ gene dataset contained 92 terminals

187 belonging to 81 species, and the combined dataset (28S + ITS1 + 5.8S + ITS2) contained 294

188 sequences belonging to 81 taxa concatenated (all sequences available from GenBank, see

189 Supplementary Table S1). The phylogenetic trees constructed from the $28 \mathrm{~S}$ and the concatenated 
190 datasets (28S + ITS1 + 5.8S + ITS2), based on BI and ML analyses, were broadly congruent. For

191 example, all clades with high nodal support values ( $P P \geq 0.95$ and bootstrap $\geq 75 \%)$ and

192 analysed with the concatenated and 28S datasets were recovered with both BI and ML (Fig. 2;

193 Supplementary Figs. S2-4). Only three clades were recovered with high nodal support values

194 (PP $\geq 0.95)$ using BI but not ML [i.e., (Gynichthys diadikidnus, Neoparacryptogonimus ovatus);

195 (Metagonimus takahashii, M. yokogawai); and (Haplorchis yokogawai (Haplorchis popelkae,

196 Haplorchis pumilio))], while only one clade received high nodal support value (bootstrap $\geq 75 \%$ )

197 with ML and not BI [i.e., (Haplorchoides sp. (Stictodora sp. isolate St1, Stictodora sp. isolate

198 St2)) (Fig. 2). Conversely, only one difference was observed between the topology of the

199 phylogenetic trees obtained from the $28 \mathrm{~S}$ and concatenated datasets with BI and ML. Namely,

200 the phylogenetic tree obtained from the ML analysis of the $28 \mathrm{~S}$ sequence dataset contained a

201 polyphyletic group (without nodal support value), i.e., Siphodera vinaledwardsii, Gynichthys

202 diakidnus, Chelediadema marjoriae, Caecincola parvulus, and Tabascotrema verai

203 (Supplementary Fig. S3). In all trees, acanthostomines were paraphyletic, with high nodal

204 support values ( $\mathrm{PP} \geq 0.95$ and bootstrap $\geq 75 \%$ ). Based on all trees, the family Cryptogonimidae

205 appears to have arisen from a paraphyletic Heterophyidae/Opisthorchiidae group. As well, all

206 trees clearly showed that the generated sequences in this study of $T$. cf. loossi and $A$. cf.

207 americanum form a monophyletic group with high nodal support values ( $\mathrm{PP} \geq 0.95$ and bootstrap

$208 \geq 75 \%$ ), respectively. These acanthostomine genera are sister to the remaining cryptogonomids.

209 Furthermore, the genus Acanthostomum is a monophyletic group with high nodal support values

210 (PP $\geq 0.95$ and bootstrap $\geq 75 \%$ ). Lastly, the 28S and ITS1-5.8S-ITS2 fragment sequences of

211 acanthostomine metacercaria from C. urophthalmus were identical to those of cercarie from $P$.

212 coronatus, and therefore both trematode stages correspond to the same taxa, A. cf. americanum. 
214 support (PP $\geq 0.95)$ and the genera Siphoderina, Belusca, Varialvus, Caulanus and Latuterus

215 form a monophyletic group (Clade I) (Fig. 2), distributed in the Indo-Pacific region (I-P). Of

216 these, the genera Belusca and Varialvus, Caulanus, and Latuterus have been found parasitizing

217 the marine fish families Haemulidae and Lutjanidae. Furthermore, Retrovarium spp. was found

218 parasitizing Lutjanidae and Haemulidae from the Indo-West Pacific (IW-P) (Fig. 2).

\section{Discussion}

220 The phylogenetic trees obtained from BI and ML analyses, inferred from the $28 \mathrm{~S}$ and

221 concatenated dataset, identified the phylogenetic position of the acanthostomines $A$. cf.

222 americanum and $T$. cf. loossi, and illustrate different intergeneric relationships among

223 cryptogonimids. Phylogenetic analyses show that the Heterophyidae and Opisthorchiidae are

224 paraphyletic as previously reported (Thaenkham et al. 2011, 2012; Fraija-Fernández et al. 2015;

225 Stoyanov et al. 2015; Borges et al. 2016), and that the family Cryptogonimidae appears to have

226 arisen from the paraphyletic Heterophyidae/Opistorchiidae. This phylogenetic inference is based

227 on a dataset of 51 taxa of Cryptogonimidae that included 24 genera. At present, the family

228 Cryptogonimidae includes 93 genera (Cribb and Gibson 2012), and we analysed almost 40\%

$229(38.75 \%)$ of recorded genera of Cryptogonimidae. Therefore, the phylogenetic inference of

230 Cryptogonimidae has an appropriate taxonomical representation, but it is still necessary to

231 complete this work with more complete sampling and sequencing of the remaining non-

232 investigated genera.

233 Based on the phylogenetic position of $A$. cf. americanus, A. burminis (which formed a

234 single clade) and $T$. cf. loossi (independent lineage), we find that the subfamily Acanthostominae 235 is paraphyletic. Therefore, the monophyly proposed for the subfamily Acanthostominae based on 
236 morphological analyses (i.e., Brooks 1980, 2004; Brooks and Caira 1982; Brooks and Holcman

237 1993) does not appear to be valid. These data support the proposed invalidity of the subfamily-

238 level division of Acanthostominae into Cryptogonimidae, as previously suggested by Miller and

239 Cribb (2008a). Therefore, it is necessary to include more acanthostomine taxa (i.e.,

240 Proctocaecum, Gymnatrema, Caimanicola) in future studies to determine their phylogenetic

241 positions and test their monophyly.

242 Based on the phylogenetic positions of Acanthostomum spp. and T. loossi in this study,

243 we postulate a probable host-specificity pattern at a supra-specific level. The adult trematodes $A$.

244 burminis, $A$. americanum and T. loossi are associated with freshwater diapsid sauropsids, i.e.,

245 Xenochrophis piscator (Schneider, 1799) (snake) (Reptilia: Colubridae) and Crocodylus

246 moreletii Duméril \& Bibron, 1851 (crocodile) (Reptilia: Crocodylidae) (Moravec 2001;

247 Jayawardena et al. 2013; Sosa-Medina et al. 2015). The molecular evidence that links the two

248 larval stages of $A$. americanum to the freshwater environment (from their intermediate hosts:

249 snails and fish) and their later development as adults in freshwater crocodiles, may reflect an

250 ecological preference to a freshwater environments. More specifically, the first larval stage (i.e.,

251 cercaria) of $A$. cf. americanum is restricted to freshwater environments due to the intermediate

252 host snail's intolerance to brackish water (Scholz et al. 2000). The trematode's intermediate and

253 definitive vertebrate hosts (Cichlasoma urophthalmus and Crocodylus moreletii) are both

254 tolerant to brackish water and can move between the two aquatic environments (Platt et al. 2010;

255 Miller et al. 2009); however, the freshwater environment is essential to completing the

256 trematode's life cycle. This assertion is supported by taxonomic records of metacercariae of $A$. cf.

257 americanum being from freshwater fishes of the families Characidae, Cichlidae, Clupeidae and

258 Poeciliidae (Sosa-Medina et al. 2015; Salgado-Maldonado 2006). 
260 marine cryptogonimids (supporting the sister-group relation found by Stoyanov et al. 2015) (Fig.

261 2). If the acanthostomine taxa are truly sister to the remaining Cryptogonomidae, there would be

262 a strong argument for the hypothesis that the cryptogonimids originated in a freshwater

263 environment and later diversified and colonized brackish and marine environments. The

264 transition from the freshwater environment to the brackish and marine environments is an

265 evolutionary process also inferred for other platyhelminth groups (e.g., Torchin et al. 2002;

266 Boeger et al. 2003; Van Steenkiste et al. 2013). Future studies may test this hypothesis regarding

267 the colonization from freshwater to marine environments (e.g., Waters and Wallis 2001;

268 Grosholz 2002; Lee and Gelembiuk 2008). The identification of the link between the cercariae

269 and metacercariae of $A$. cf. americanum may represent a step in the understanding of the

270 evolutionary strategies employed within different aquatic environments and the potential

271 repercussions on food webs (e.g., Shoop 1988; Dobson et al. 2006; Poulin 2006).

272 It is noteworthy that the hydrobiid snail $P$. coronatus is highly susceptible to trematode

273 infection, as it has been reported to harbour 12 trematode species, i.e., Genarchella astyanactis

274 Watson 1976; Echinochasmus leopoldinae Scholz et al. 1996; Echinochasmus macrocaudatus

275 Ditrich et al. 1996; Saccocoelioides cf. sogandoresi Lumsden 1963; Crassicutis cichlasomae

276 Manter 1936; Homalometridae gen. sp.; Oligogonotylus manteri Watson 1976; A. (Phagicola)

277 nana Ransom 1920; Ascocotyle (Ascocotyle) sp.; Xiphidiocercaria type 1, Xiphidiocercaria type

2782 and Xiphidiocercaria type 3 (Scholz et al. 2000). The record of $A$. cf. americanum in $P$.

279 coronatus is a new cercaria record for this snail. However, unfortunately, we did not collect

280 sufficient cercariae of $A$. cf. americanum to describe their morphology. 
283 2008b; Miller et al. 2010b) (Fig. 2). Based on the diversity of genera in this clade, possible

284 taxonomic implications include the erection of a new taxonomic hierarchy at the subfamily level.

285 Future studies based on morphological evidence may support or reject this taxonomic inference.

286 Presently, more than 50 cryptogonimid taxa have been recorded from fishes belonging to the

287 Lutjanidae and Haemulidae of the IW-P (Miller and Cribb 2007b; Cribb et al. 2016), reflected in

288 the phylogenetic topology revealed in this study; e.g., the genera Beluesca, Varialvus, Caulanus,

289 Latuterus, Siphomutabilus, Metadena, Chelediadema, and Gynichthys (Fig. 2) (Miller and Cribb

290 2007c, 2009, 2013; Miller et al. 2010a,b, 2011; Overstreet et al. 2009). Furthermore, Adlardia

291 novaecaledoniae has been found in Nemipteridae from the Indo-West Pacific (Miller et al.

292 2009). On the other hand, previous records of Euryakaina spp. and Retrovarium spp. have been

293 found in the families Lutjanidae and Haemulidae families from the Indo-West Pacific, and were

294 attributed by the authors to a host specificity pattern at the supra-specific level (Miller et al.

295 2007b, 2010a, 2011). Similarly, cases of monophyletic groups from this study originating from

296 specific families could indicate cases of host specificity (probably resulting from co-divergence

297 (Page 2003; Martínez-Aquino 2016)), although we cannot rule out the possibility of these cases

298 are an artefact of sampling bias. Future taxonomical studies of cyryptogonomid trematodes from

299 marine fishes from other parts of the world will shed more light on host-specificity patterns (e.g.,

300 Barger 2010; Montoya-Mendoza et al. 2014).

301 Additionally, several non-acanthostomine cryptogonimid clades associated with the

302 freshwater environment are specialist parasites of particular families of freshwater fishes from

303 North and Central America; e.g., Caecincola parvulus is associated with Centrarchidae from 
304 North America (NA), and Tabascotrema verai, O. mayae and O. manteri are associated with

305 Cichlidae from Central America (CA) (Choudhury et al. 2016). Even though these groups did not

306 have valid nodal support in this study (Fig. 2), it is important to mention three points. First, the

307 freshwater cryptogonimids appear to have arisen from among the marine taxa. Second, $C$.

308 parvulus and Oligogonotylus spp. occur in freshwater fishes as both adults and metacercariae

309 (Stoyanov et al. 2015; Choudhury et al. 2016). Third, considering that centrarchids and cichlids

310 are both members of Percomorpha and have marine affinities, Choudhury et al. (2016) suggested

311 that a close relationship exists between Middle-American cryptogonimids of cichlids and

312 cryptogonimids of North American centrarchids. The phylogenetic relationship we found

313 between cryptogonimids of cichlids and centrarchids supports this hypothesis. However, recent

314 records of $C$. parvulus from other freshwater fish families must also be considered before final

315 conclusions are made (McAllister et al. 2015, 2016).

316 Studies of cryptogonimids (and trematodes in general) are negatively impacted by the

317 lack of taxonomical records of helminth parasites of freshwater and marine fishes of different

318 regions (Scholz and Choudhury 2014; Cribb et al. 2016; Vidal-Martínez et al. 2016), as well as

319 the lack of knowledge concerning intermediate and definitive host life cycles (Cribb and Bray

320 2011; Blasco-Costa and Poulin 2017). This has led to a reduction in postulated evolutionary

321 hypotheses on the diversification patterns of parasites. However, the development of

322 phylogenetic hypotheses as presented here can provide a modern framework in parasite

323 evolutionary ecology (e.g., Littlewood 2011; Gómez Nichols 2013; Poulin et al. 2016).

\section{Acknowledgments}

325 Thanks to staff of the laboratory of Patología Acuática: Clara Vivas Rodríguez, Gregory Arjona-

326 Torres, Ana L. May-Tec, Francisco Puc Itzá, Nadia Herrera Castillo, Jhonny G. García-Teh, 
327 Arturo Centeno-Chale, Germán López-Guerra, Daniel Aguirre-Ayala and Efraín Sarabia from

328 CINVESTAV-IPN, Unidad Mérida, México. We are grateful to Abril Gamboa and José García

329 Maldonado for their technical assistance in the molecular lab. We also thank Dr. Fadia Sara

330 Ceccarelli who reviewed the first draft of this manuscript and made very useful suggestions of

331 the phylogenetic analyses that we present in this contribution. The manuscript greatly benefited

332 from comments of Dr. Terry Miller and two anonymous referees.

333 We thank the American Journal Experts for editing the English text.

\section{References}

337

338

Aguirre-Macedo, M.L., May-Tec, A. L., Martínez-Aquino, A., Cremonte, F., \& Martorelli, S. R. (2017). Diversity of helminth parasites in aquatic invertebrate hosts in Latin America: How much do we know? Journal of Helminthology, 91, 137-149. http://dx.doi.org/10.1017/S0022149X16000547

Barger, M. A. (2010). A new species of Caecincola (Trematoda: Cryptogonimidae) from spotted bass (Micropterus punctulatus) in the Big Thicket National Preserve, Texas, U.S.A. Comparative Parasitology, 77, 6-8. http://dx.doi.org/10.1654/4417.1

Bray, R. A., Waeschenbach, A., Cribb, T. H., Weedall, G. D., Dyal, P. \& Littlewood D. T. J. 2009. The phylogeny of the Lepocreadioidea (Platyhelminthes, Digenea) inferred from nuclear and mitochondrial genes: Implications for their systematics and evolution. Acta Parasitologica, 54, 310-329. http://dx.doi.org/10.2478/s11686-009-0045-z

Blasco-Acosta, I., \& Poulin, R. (2017). Parasite life-cycle studies: a plea to resurrect an old parasitological tradition. Journal of Helminthology, 7, 1-10. 
351 Boeger, W. A., Kritsky, D. C., \& Pie, M. R. (2003). Context of diversification of the viviparous Gyrodactylidae (Platyhelminthes, Monogenoidea). Zoologica Scripta, 32, 437-448. http://dx.doi.org/10.1046/j.1463-6409.2003.00130.x

354

355

356

357

358

360

361

362

363

364

365

366

367

368

369

370

371

372

Borges, J. N., Costa, V. S., Mantovani, C., Barros, E., Santos, E. G. N., Mafra, C. L., \& Santos, C. P. (2016). Molecular characterization and confocal laser scanning microscopic study of Pygidiopsis macrostomum (Trematoda: Heterophyidae) parasites of guppies Poecilia vivipara. Journal of Fish Diseases, 40, 191-203. http://dx.doi.org/10.1111/jfd.12504

Bowles, J., Blair, D., \& McManus, D. P. (1995). A molecular phylogeny of the human schistosomes. Molecular Phylogenetics and Evolution, 4, 103-109. http://dx.doi.org/10.1006/mpev.1995.1011

Brooks, D. R. (1980). Revision of the Acanthostominae Poche, 1926 (Digenea: Cryptogonimidae). Zoological Journal of the Linnean Society, 70, 313-382. http://dx.doi.org/10.1111/j.1096-3642.1980.tb00855.x

Brooks, D. R. (2004). Comments on the gonotyl of Proctocaecum macroclemidis (Tkach and Snyder, 2003) n. comb. (Digenea: Acanthostomidae: Acanthostominae), with a key to the genera of Acanthostominae and a new phylogenetic for Proctocaecum Baugh, 1957. Journal of Parasitology, 90, 594-597. http://dx.doi.org/10.1645/GE-133R

Brooks, D. R., \& Caira, J. N. (1982). Atrophecaecum lobacetabulare n. sp. (Digenea: Cryptogonimidae: Acanthostominae) with discussion of the generic status of Paracanthosthomum Fischthal and Kuntz, 1965 and Ateuchocephala Coil and Kuntz, 1960. Proceedings of the Biological Society of Washington, 95, 223-231.

Brooks, D. R., \& Holcman, B. (1993). Revised classification and phylogenetic hypothesis for the 
373

374

375

376

377

378

379

380

381

382

383

384

385

386

387

388

389

390

391

392

393

394

395

Acanthostominae Looss, 1899 (Digenea: Opisthorchiformes: Cryptogonimidae). Proceedings of the Biological Society of Washington, 106, 207-220.

Castresana, J. (2000). Selection of conserved blocks from multiple alignments for their use in phylogenetic analysis. Molecular Biology and Evolution, 17, 540-552. http://dx.doi.org/10.1093/oxfordjournals.molbev.a026334

Choudhury, A., Aguirre-Macedo, M. L., Curran S. S., Ostrowski de Núñez, M., Overstreet, R. M., Pérez-Ponce de León, G., \& Portes Santos, C. (2016). Trematode diversity in freshwater fishes of the Globe II: 'New World'. Systematic Parasitology, 93, 271-282. http://dx.doi.org/10.1007/s11230-016-9632-1

Cribb, T. H., \& Gibson, D. (2010). Cryptogonimidae Ward, 1917. World register of marine species. http://www.marinespecies.org/aphia.php?p=taxdetails\&id=108440, (accessed 1704-20).

Cribb, T. H., \& Bray, R. A. (2011). Trematode families and genera: have we found them all? Trends in Parasitology, 27, 149-154. http://dx.doi.org/10.1016/j.pt.2010.12.008

Cribb, T. H., Bray, R. A., Diaz, P. E., Huston, D. C., Kudlai, O., Martin, S. B., Yong, R.Q.-Y., \& Cutmore, S. C. (2016). Trematodes of fishes of the Indo-west Pacific: told and untold richness. Systematic Parasitology, 93, 237-247. http://dx.doi.org/10.1007/s11230-016$\underline{9625-0}$

Ditrich, O., Scholz, T., Aguirre-Macedo, L., \& Vargas-Vázquez, J. (1997). Larval stages of trematodes from freshwater molluscs of the Yucatan Peninsula, Mexico. Folia Parasitolica, 44, 109-127.

Dobson, A., Lafferty, K. \& A. Kuris. (2006). Parasites and food webs. In M. Pascual \& Dunne J. A. (Eds.), Ecological networks: linking structure to dynamics in food webs (pp. 119-136). 
397

398

399

400

401

402

403

404

405

406

407

408

409

410

411

412

413

414

415

416

417

418

419

Drummond, A. J., Ashton, B., Buxton, S., Cheung, M., Cooper, A., Duran, C., Field, M., Heled, J., Kearse, M., Markowitz, S., Moir, R., Stones-Havas, S., Sturrock, S., Thierer, T., \& Wilson, A. (2010) Geneious v5.0.4 Available at: http://www.geneious.com/. (accessed 1 December 2016).

Felsenstein, J. (1985). Confidence limits on phylogenies: an approach using the bootstrap. Evolution, 39, 783-791. http://dx.doi.org/10.2307/2408678

Fernandes, B. M. M., Cohen, S. C., Mendonça, H. S., \& Justo, M. C. N. (2013). Annakohniella travassosi n. gen., n. sp. (Digenea: Cryptogonimidae) parasite of Rhaphiodon vulpinus (Pisces: Cynodontidae) from Brazil. Comparative Parasitology, 80, 17-21. http://dx.doi.org/10.1654/4582.1

Fraija-Fernández, N., Olson, P. D., Crespo, E.A., Raga, J. A., Aznar, F. J., \& Fernández, M. (2015). Independent host switching events by digenean parasites of cetaceans inferred from ribosomal DNA. International Journal for Parasitology, 45, 167-173. http://dx.doi.org/10.1016/j.ijpara.2014.10.004

Gómez, A. \& Nichols, E. (2013). Neglected wild life: Parasitic biodiversity as a conservation target. International Journal for Parasitology, Parasites and Wildlife, 2, 222-227. http://dx.doi.org/10.1016/j.ijppaw.2013.07.002

Grosholz, E. (2002). Ecological and evolutionary consequences of coastal invasions. Trends in Ecology and Evolution, 17, 22-27. http://dx.doi.org/10.1016/S0169-5347(01)02358-8

Gray, J. E. (1830). Illustrations of Indian Zoology; chiefly selected from the collection of MajorGeneral Hardwicke, F.R.S. Volumen II. London, Treuttel, Wurtz, Treuttel, Jun and Richter. 
420 Jayawardena, U. A., Tkach, V. V., Navaratne, A. N., Amerasinghe, P. H., \& Rajakaruna, R. S.

421 (2013). Malformations and mortality in the Asian Common Toad induced by exposure to

422

423 Pleurolophocercous cercariae (Trematoda: Cryptogonimidae). Parasitology

International, 62, 246-252. http://dx.doi.org/10.1016/j.parint.2013.01.003

424

425

426

427

428

429

430

431

432

433

434

435

436

437

438

439

440

441

442

Jukes, T. H., \& Cantor, C. R. Evolution of protein molecules. In H. M. Munro (Ed.), Mammalian protein metabolism (pp. 21-132). New York: Academic Press, 1969. ISBN-10: 0-7167$3136-3$

Katoh, K., \& Standley, D. M. (2016). A simple method to control over-alignment in the MAFFT multiple sequence alignment program. Bioinformatics, 32, 1933-1942. http://dx.doi.org/10.1093/bioinformatics/btw108

Lanfear, R., Calcott, B., Ho, S. Y., \& Guindon, S. (2012). Partition Finder: combined selection of partitioning schemes and substitution models for phylogenetic analyses. Molecular Biology and Evolution, 29, 1695-1701. http://dx.doi.org/10.1093/molbev/mss020

Lanfear, R., Calcott, B., Kainer, D., Mayer, C., \& Stamatakis, A. (2014). Selecting optimal partitioning schemes for phylogenomic datasets. BMC Evolutionary Biology, 14:82. http://dx.doi.org/10.1186/1471-2148-14-82

Lee, C. E., \& Gelembiuk, G. W. (2008). Evolutionary origins of invasive populations. Evolutionary Applications, 1, 427-448. http://dx.doi.org/10.1111/j.1752$\underline{4571.2008 .00039 . x}$

Littlewood, D. T. J. (2011). Systematics as a cornerstone of parasitology: overview and preface. Parasitology, 138, 1633-1637. http://dx.doi.org/10.1017/S0031182011001533

Martínez-Aquino, A. (2016). Phylogenetic framework for coevolutionary studies: a compass for exploring jungles of tangled trees. Current Zoology, 62, 393-403. 
444

445

446

447

448

449

450

451

452

453

454

455

456

457

458

459

460

461

462

463

464

465

McAllister, C. T., Font, W. F., Connior M. B., Robison, H. W., Fayton, T. J., Stokes, N. G., \& Criscione C. D. (2015). Trematode parasites (Digenea) of the Slender Madtom Noturus exilis and Black River Madtom Noturus maydeni (Siluriformes: Ictaluridae) from Arkansas, U.S.A. Comparative Parasitology, 82, 137-143. http://dx.doi.org/10.1654/4714.1

McAllister, C. T., Bursey, C. R., Robison, H. W., Connior, M. B., \& Trauth, S. E. (2016). New records of helminth parasites (Trematoda, Cestoda, Nematoda) from fishes in the Arkansas and Red River Drainages, Oklahoma. Proceedings of the Oklahoma Academy of Science, 96, 83-92. http://dx.doi.org/10.1654/4714.1

Miller, M. A., Pfeiffer, W., \& Schwartz, T. (2010). Creating the CIPRES Science Gateway for inference of large phylogenetic trees'. Proceedings of the Gateway Computing Environments Workshop (GCE), 14 Nov. 2010, New Orleans, LA: IEEE Computer Society. pp. 1-8.

Miller, R. R., Minckley, W. L., \& Norris, S. M. (2009) Peces dulceacuícolas de México. CONABIO, México City, México. ISBN: 978-607-7607-20-5

Miller, T. L., \& Cribb, T. H. (2007a). Coevolution of Retrovarium n. g. (Digenea: Cryptogonimidae) in Lutjanidae and Haemulidae (Perciformes) in the Indo-West Pacific. International Journal for Parasitology, 37, 1023-1045. http://dx.doi.org/10.1016/j.ijpara.2007.01.006

Miller, T. L., \& Cribb, T. H. (2007b). Two new cryptogonimid genera Beluesca n. gen. and Chelediadema n. gen. (Digenea: Cryptogonimidae) from tropical Indo-West Pacific Haemulidae (Perciformes). Zootaxa, 1543, 45-60. 
467

468

469

470

471

472

473

474

475

476

477

478

479

480

481

482

483

484

485

486

487

488

Miller, T. L., \& Cribb, T. H. (2007c). Two new cryptogonimid genera (Digenea, Cryptogonimidae) from Lutjanus bohar (Perciformes, Lutjanidae): analyses of ribosomal DNA reveals wide geographic distribution and presence of cryptic species. Acta Parasitologica, 52, 104-113. http://dx.doi.org/10.2478/s11686-007-0019-y

Miller, T. L., \& Cribb, T. H. (2008a). Family Cryptogonimidae Ward, 1917. In R. A. Bray, D. I., Gibson, \& A. Jones (Eds.), Keys to the Trematoda. Wallingford: CAB International (Vol. 3, pp. 51-112). ISBN 0-85199-547-0

Miller, T. L. \& Cribb, T. H. (2008b). Eight new species of Siphoderina Manter, 1934 (Digenea, Cryptogonimidae) infecting Lutjanidae and Haemulidae (Perciformes) off Australia. Acta Parasitologica, 53, 344-364. http://dx.doi.org/10.2478/s11686-008-0053-4

Miller, T. L. \& Cribb, T. H. (2009). Gynichthys diakidnus n. g., n. sp. (Digenea: Cryptogonimidae) from the grunt Plectorhinchus gibbosus (Lacépède, 1802) (Perciformes: Haemulidae) off the Great Barrier Reef, Australia. Systematic Parasitology, 74, 103-112. http://dx.doi.org/10.1007/s11230-009-9194-6

Miller, T. L., \& Cribb, T. H. (2013). Dramatic phenotypic plasticity within species of Siphomutabilus n. g. (Digenea: Cryptogonimidae) from Indo-Pacific caesionines (Perciformes: Lutjanidae). Systematic Parasitology, 86, 101-112. http://dx.doi.org/10.1007/s11230-013-9436-5

Miller, T. L., Bray, R. A., Goiran, C., Justine, J.-L., \& Cribb, T. H. (2009). Adlardia novaecaledoniae n. g., n. sp. (Digenea: Cryptogonimidae) from the fork-tailed threadfin bream Nemipterus furcosus (Val.) (Perciformes: Nemipteridae) off New Caledonia. Systematic Parasitology, 73, 151-160. http://dx.doi.org/10.1007/s11230-009-9187-5 
489 Miller, T. L., Adlard, R. D., Bray, R. A., Justine, J.-L., \& Cribb, T. H. (2010a). Cryptic species

490 of Euryakaina n. g. (Digenea: Cryptogonimidae) from sympatric lutjanids in the Indo-

491

492 West Pacific. Systematic Parasitology, 77, 185-204. http://dx.doi.org/10.1007/s11230-

493

494

495

496 $\underline{010-9266-7}$

Miller, T. L., R. A. Bray, Justine, J.-L., \& Cribb, T. H. (2010b). Varialvus gen. nov. (Digenea, Cryptogonimidae), from species of Lutjanidae (Perciformes) off the Great Barrier Reef, New Caledonia and the Maldives. Acta Parasitologica, 55, 327-339.

497

Miller, T. L., Bray, R. A., \& Cribb T. H. (2011). Taxonomic approaches to and interpretation of 498

499 host specificity of trematodes of fishes: lessons from the Great Barrier Reef. Parasitology, 138, 1710-1722. http://dx.doi.org/10.1017/S0031182011000576

Montoya-Mendoza, J., Jiménez-Badillo, L., Salgado-Maldonado, G., \&

501

502

503 Mendoza-Franco, E. F. (2014). Helminth parasites of the Red Snapper, Lutjanus campechanus (Perciformes: Lutjanidae) from the Reef Santiaguillo, Veracruz, Mexico.

504 505 Journal of Parasitology, 100, 868-872. http://dx.doi.org/10.1645/13-429.1

Moravec, F. (2001). Some helminth parasites from Morelet's crocodile, Crocodyle moreletii, from Yucatan, Mexico. Folia Parasitologica, 48, 47-62.

507 http://dx.doi.org/10.14411/fp.2001.008

Nelson, J. S. (2006). Fishes of the World. Fourth Edition. John Wiley and Sons, Inc. Print USA.

Overstreet, R. M., Cook, J. C., \& Heard, R. W. (2009). Trematoda (Platyhelminthes) of the Gulf 509 of Mexico. In D. L. Felder, \& D. K. Camp. (Eds.), Gulf of Mexico-Origins, Waters, and Biota. Biodiversity (pp. 419-486). Texas A\&M University Press, College Station. ISBN $1603442693,9781603442695$. 
512 Page, R. D. M. (2003). Tangled Trees: Phylogeny, Cospeciation, and Coevolution.

513 Chicago: University of Chicago Press. SBN-10: 0226644669

514 Palumbi, S. R. (1996). Nucleic acids II. The polymerase chain reaction. In D. Hillis, C. Moritz, 515 \& B. K. Mable (Eds.), Molecular systematics, (pp. 321-383). Sinauer, Sunderland, $516 \quad$ Massachusetts. ISBN-10: 0878932828

517 Platt, S. G., Sigler, L., \& Rainwater, T. R. (2010). Morelet's crocodile Crocodylus moreletii. In S. 518 C. Manolis \& C. Stevenson (Eds.), Crocodiles. Status Survey and Conservation Action Plan (pp. 79-83). Crocodile Specialist Group Darwin. ISBN: 2-8317-0441-3

520 Posada, D. (2003). Using MODELTEST and PAUP* to select a model of nucleotide substitution. In A. D. Baxevanis, D. B. Davison, R. D. M. Page, G. A. Petsko, L. D. Stein, \& G. D. Stormo (Eds.), Current Protocols in Bioinformatics, (pp. 6.5.1-6.5.14). New York: John Wiley \& Sons. Unit 6.5. http://dx.doi.org/10.1002/0471250953.bi0605s00

526 Poulin, R., Blasco-Costa, I. \& Randhawa, H. S. (2016). Integrating parasitology and marine ecology: seven challenges towards greater synergy. Journal of Sea Research, 113, 3-10. http://dx.doi.org/10.1016/j.seares.2014.10.019

Razo-Mendivil, U., Rosas-Valdez, R., \& Pérez-Ponce de León, G. (2008). A new Cryptogonimid (Digenea) from the mayan cichlid, Cichlasoma urophthalmus (Osteichthyes: Cichlidae), in several localities of the Yucatan Peninsula, Mexico. Journal of Parasitology, 94, 1371-1378. http://dx.doi.org/10.1645/GE-1546.1

Razo-Mendivil, U., Vázquez-Domínguez, E., Rosas-Valdez, R., Pérez-Ponce de León, G. \& Nadler, S. A. (2010). Phylogenetic analysis of nuclear and mitochondrial DNA reveals a 
535

536

537

538

539

540

541

542

543

544

545

546

547

548

549

550

551

552

553

554

555

556

557

complex of cryptic species in Crassicutis cichlasomae (Digenea: Apocreadiidae), a parasite of Middle-American cichlids. International Journal for Parasitology, 40, 471486. http://dx.doi.org/10.1016/j.ijpara.2009.10.004

Ronquist, F., Teslenko, M., van der Mark, P., Ayres, D. L., Darling, A., Höhna, S., Larget, B., Liu, L., Suchard, M. A. \& Huelsenbeck, J. P. (2012). MrBayes 3.2: efficient Bayesian phylogenetic inference and model choice across large model space. Systematic Biology, 61, 539-542. http://dx.doi.org/10.1093/sysbio/sys029

Saiki, R. K., Gelfand, D. H., Stoffel, S., Scharf, S. J., Higuchi, R., Horn, G.T., Mullis, K. B. \& Erlich, H. A. (1988). Primer-directed enzymatic amplification of DNA with a thermostable DNA polymerase. Science, 239, 487-491. http://dx.doi.org/10.1126/science. 2448875

Salgado-Maldonado, G. (2006). Checklist of helminth parasites of freshwater fishes from Mexico. Zootaxa, 1324, 1-357.

Sánchez Herrera, O., López Segurajáuregui, G., García Naranjo Ortiz de la Huerta, A. \& Benítez Díaz, H. (2011). Programa de monitoreo del cocodrilo de pantano (Crocodylus moreletii) México-Belice-Guatemala. México. Comisión Nacional para el Conocimiento y Uso de la Biodiversidad. México.

Schwarz, G. (1978). Estimating the dimension of a model. Annals of Statistics, 6, 461-464. http://dx.doi.org/10.1214/aos/1176344136

Scholz, T., \& Choudhury, A. (2014). Parasites of freshwater fishes in North America: why so neglected? Journal of Parasitology, 100, 26-45. http://dx.doi.org/10.1645/13-394.1

Scholz, T., Aguirre-Macedo, M. L., Flores Días de Léon, A. T. S., \& Ditrich, O. (2000). Larval stages of trematodes in Mexican freshwater molluscs: a review of present state and 
558

559

560

561

562

563

564

565

566

567

568

569

570

571

572

573

574

575

576

577

578

579

580

methodology for future research. In G. Salgado-Maldonado, A. N. García-Aldrete, \& V. M. Vidal-Martínez (Eds.), Metazoan parasites in the neotropics: a systematic and ecological perspective (pp. 77-100). Instituto de Biología, UNAM. México. ISBN: 9683688276

Shoop, W. L. (1988). Trematode transmission patterns. Journal of Parasitology, 74, 46-59. http://dx.doi.org/10.2307/3282478

Sosa-Medina, T., Vidal-Martínez, V. M., \& Aguirre-Macedo, M. L. (2015). Metazoan parasites of fishes from the Celestun coastal lagoon, Yucatan, Mexico. Zootaxa, 4007, 529-544. http://dx.doi.org/10.11646/zootaxa.4007.4.4

Stamatakis, A. (2006). Phylogenetic models of rate heterogeneity: A high performance computing perspective. Parallel and Distributed Processing Symposium, 2006. Rhodos, Greece. http://dx.doi.org/10.1109/IPDPS.2006.1639535

Stamatakis, A. (2014). RAxML version 8: a tool for phylogenetic analysis and post-analysis of large phylogenies. Bioinformatics, 30, 1312-1313. http://dx.doi.org/10.1186/1471-214814-82.

Stoyanov, B., Neov, B., Pankov, P., Radoslavov, G., Hristov, P., \& Georgiev, B. B. (2015). Redescription of Aphalloides coelomicola Dollfus, Chabaud \& Golvan, 1957 (Digenea, Opisthorchioidea) based on specimens from Knipowitschia caucasica (Berg) (Actinopterygii, Gobionellidae) from a Black Sea lagoon, with comments on the systematic position of the genus. Systematic Parasitology, 91, (1-12). http://dx.doi.org/10.1007/s11230-015-9559-y

Talavera, G., \& Castresana, J. (2007). Improvement of phylogenies after removing divergent and ambiguously aligned blocks from protein sequence alignments. Systematic Biology, 56, 
582 Thaenkham, U., Nawa, Y., Blair, D., \& Pakdee, W. (2011). Confirmation of the paraphyletic 583 relationship between families Opisthorchiidae and Heterophyidae using small and large 584 subunit ribosomal DNA sequences. Parasitology International, 60, 521-523. $585 \quad$ http://dx.doi.org/10.1016/j.parint.2011.07.015

586 Thaenkham, U., Blair, D., Nawa, Y., \& Waikagul, J. (2012). Families Opisthorchiidae and 587 Heterophyidae: Are they distinct? Parasitology International, 61, 90-93.

588 http://dx.doi.org/10.1016/j.parint.2011.06.004

589 Tkach, V. J., \& Bush, S. E. (2010). Serpentoanisocladium sinense n. g., n. sp. (Digenea:

590 Cryptogonimidae) from the eastern water snake Sinonatrix percarinata (Boulenger)

591 (Serpentes: Colubridae) in Guizhou Province, China. Systematic Parasitology, 76, 205592 210. http://dx.doi.org/10.1007/s11230-010-9246-y

593 Tkach, V., Pawlowski, J., \& Mariaux, J. (2000). Phylogenetic analysis of the suborder $594 \quad$ Plagiorchiata (Platyhelminthes, Digenea) based on partial lsrDNA sequences. 595 596 International Journal for Parasitology, 30, 83-93. http://dx.doi.org/10.1016/S00207519(99)00163-0

597 Torchin, M. E., Lafferty, K. D., \& Kuris, A. M. (2002). Parasites and marine invasions. 598 Parasitology, 124, S137-S151. http://dx.doi.org/10.1017/S0031182002001506

599 Van Steenkiste, N., Tessens, B., Willems, W., Backeljau, T., Jondelius, U., \& Artois, T. (2013).

600 A comprehensive molecular phylogeny of Dalytyphloplanida (Platyhelminthes:

601 Rhabdocoela) reveals multiple escapes from the marine environment and origins of $602 \quad$ symbiotic relationships. PLoS ONE, 8(3) e59917.

603 http://dx.doi.org/10.1371/journal.pone.0059917 
604 Vidal-Martínez, V. M., Scholz, T., Aguirre-Macedo, M. L., González-Solís, D., \& Mendoza-

605 Franco, E. F. (2001). Atlas of the helminth parasites of cichlid fishes of Mexico.

606 Academia, Prague, Czech Republic. ISBN-10: 8020008209

607 Vidal-Martínez, V. M., Torres-Irineo, E., \& Aguirre-Macedo, M. L. (2016). A century (1914-

608 2014) of studies on marine fish parasites published in The Journal of Parasitology. In J.

609 Janovy \& G. W. Esch (Eds.), A Century of Parasitology: Discoveries, ideas and lessons

610 learned by scientists who published in the Journal of Parasitology, 1914-2014 (pp. 57-

611 76). E-John Wiley and Sons, Ltd, Chichester, UK.

$612 \quad$ http://dx.doi.org/10.1002/9781118884799.ch5

613 Waters, J. M., \& Wallis, G. P. (2001). Cladogenesis and loss of the marine life-history phase in

614 freshwater galaxiid fishes (Osmeriformes: Galaxiidae). Evolution, 55, 587-597.

615 http://dx.doi.org/10.1554/0014-3820(2001)055[0587:CALOTM]2.0.CO;2

616 Yang, Z. (1994). Maximum likelihood phylogenetic estimation from DNA sequences with

617 variable rates over sites. Journal of Molecular Evolution, 39, 306-314.

$618 \quad$ http://dx.doi.org/10.1007/BF00160154

619 Yang, Z. (1996). Among-site rate variation and its impact on phylogenetic analyses. Trends in

620 Ecology \& Evolution, 11, 367-372 https://doi.org/10.1016/0169-5347(96)10041-0 


\section{Figure 1 (on next page)}

Map of the study area, Yaxaá spring, Celestun coastal lagoon, Yucatan, Mexico. 


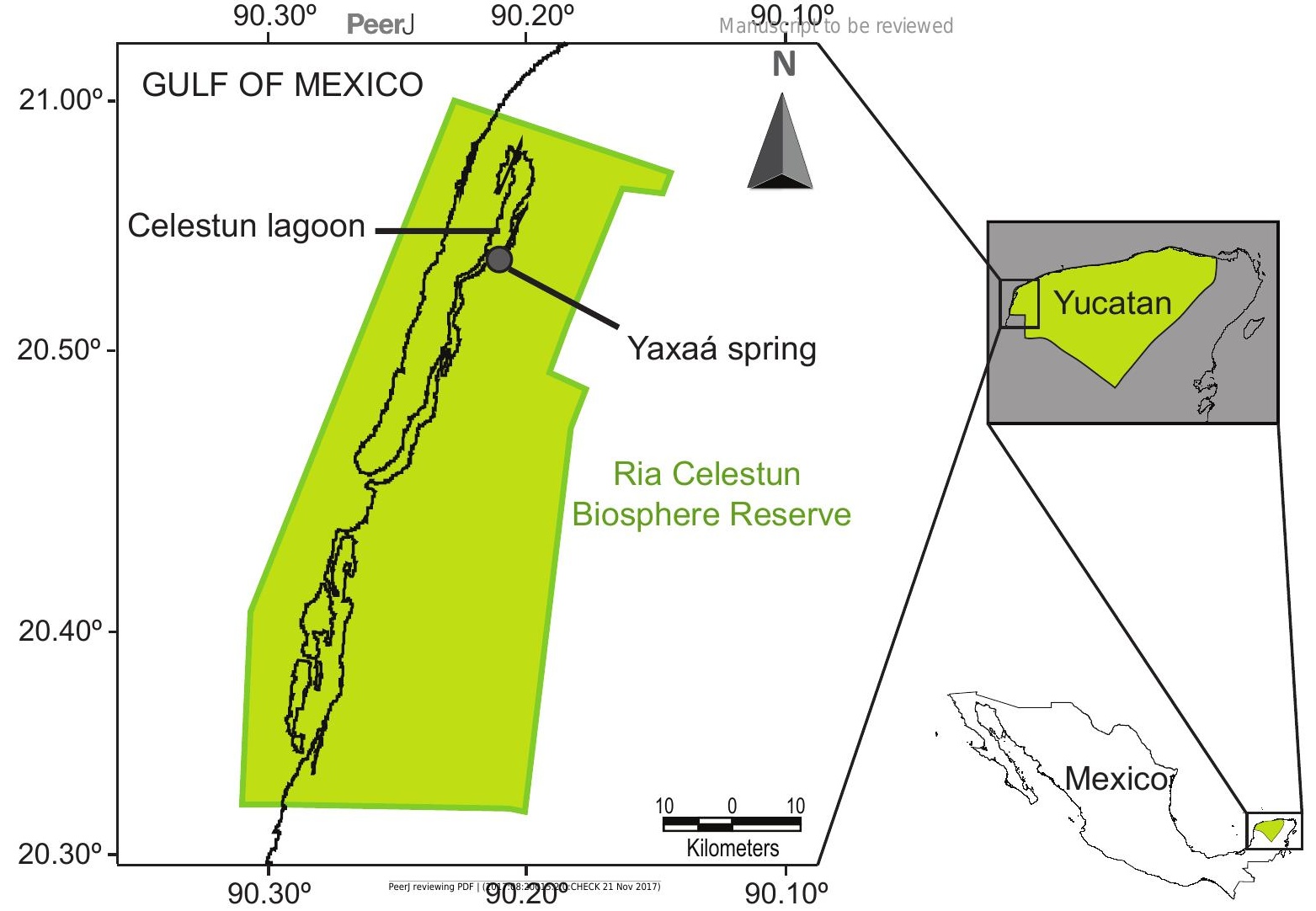




\section{Figure 2 (on next page)}

Phylogenetic tree obtained from Bayesian inference analysis of the concatenated data $(28 \mathrm{~S}+$ ITS1 + 5.8S + ITS2) of species of the Cryptogonimidae.

The scale bar represents the number of nucleotide substitutions per site. Codes following taxon names are cross-referenced in Table 1 and Supplementary Table S1. Filled black circles above and white circles below the branches represent Bayesian posterior probability $\geq 0.95$ and Maximum likelihood bootstrap support values $\geq 75 \%$, respectively. Diffused green $=$ Freshwater environment; Diffused green-yellow = Brackish environment; Diffused blue = Marine environment; $\mathrm{IH}=$ Intermediate host; $\mathrm{DH}=$ Definitive host; ? = Intermediate host unknown. I-P = Indo-Pacific; IW-P = Indo-west Pacific; $C A=$ Central America; GM = Gulf of Mexico; NA = North America; EA = Eastern Atlantic; Se-A \& SL = South-eastern Asia and Sri Lanka. The black snail outline corresponds to Pyrgophorus coronatus. The black fish outline corresponds to Cichlasoma urophthalmus. The black crocodile outline corresponds to Crocodylus moreletii. The black fishes outline on the remaining Cryptogonomidae refer to host specificity at family (ies) recording to species, species groups or genus (black line) of cryptogonomids. The animals' silhouettes were modified from Ditrich et al. (1997) (snail); Gray (1830) (snake); Nelson (2006) (fishes), and Sánchez-Herrera et al. (2011) (crocodile). The cryptogonomid taxa without black fish outline are not specific to one host. See text for more details. 


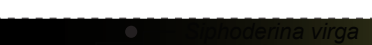

O- Siphoderina territans

_ Siphoderina hirastic

O Siphoderina grunnitus

- Siphoderina quasispina

OL- Siphoderina jactus

- $\angle$ Siphoderina infirma

- Siphoderina poulini

Siphoderina subuterus

Beluesca longicolla

Varialvus jenae charadrus

Caulanus thomasi Varialvus lacertus

- Latuterus maldivensis

으 Latuterus tkachi

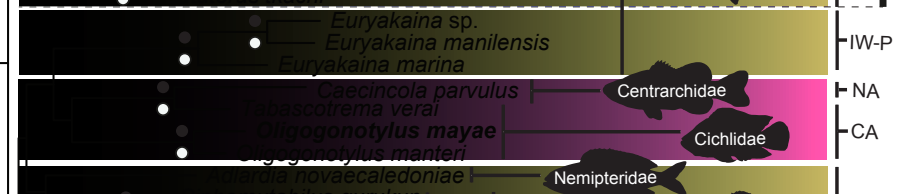

- Adlardia

- _ Siphomutabilus gurukun

o Siphomutabilus raritas

Metadena lutiani

- Lobosorchis tibaldiae

o Lobosorchis polygongylus

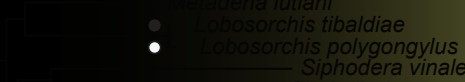

Siphodera vinaledwardsii - GM

- Gynichthys diakidnus Neoparacryptogonimus ovatus

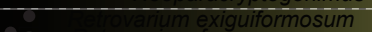

- Retrovarium formosum

LL Retrovarium valdeparvum

Retrovarium amplorificium

L Retrovarium snyderi

- Retrovarium planum

- Retrovarium brooksi

O - Retrovarium manteri

- Retrovarium mariae

- Detrovarium sablae

Retrovarium gardner

Mitotrema anthostomatum

Aphalloides coelomicola

Timoniella cf. loossi 4

Timoniella cf. loossi 1

Timoniella cf. loossi 3

O Timoniella cf. loossi 2

Timoniella cf. loossi 5

Acanthostomum cf. americanum 3c

Acanthostomum cf. americanum $3 \mathrm{~m}$

Acanthostomum cf. americanum $2 \mathrm{~m}$

Acanthostomum cf. americanum $1 \mathrm{~m}$

Acanthostomum cf. americanum 1c

Acanthostomum cf. americanum 2c

Acanthostomum burminis

- Acanthostomum burminis

OL Acanthostomum burminis

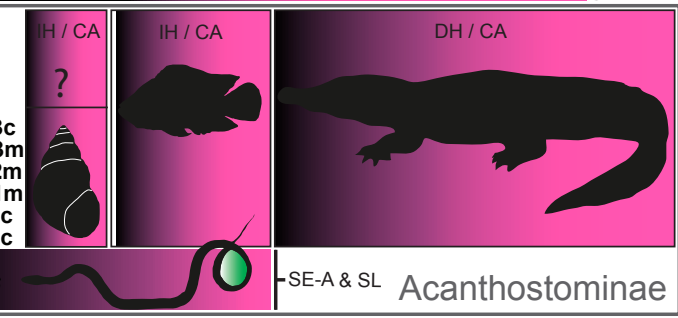

- Ōpisthórchis nóve-rca

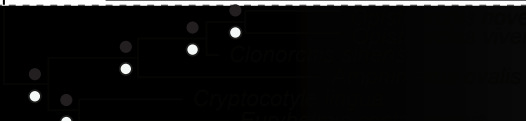

O Cryptocotyle lingua

- Metagonimus takahashi

Metagonimus yokogawai

Metagonimus miyatai

- Metagonimus katsuragonimus hakubaensis

o Metagonimus otsurui

Metagonimoides oregonensis

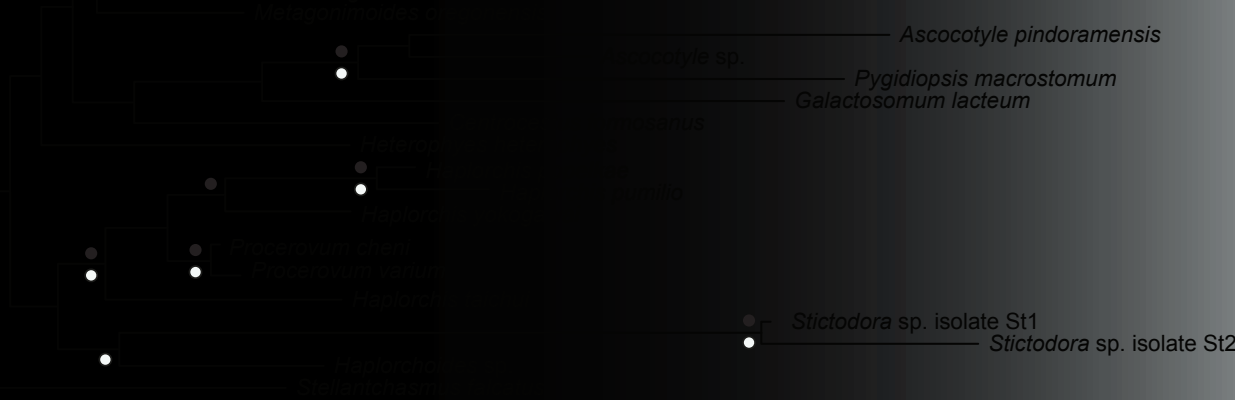




\section{Table $\mathbf{1}$ (on next page)}

GenBank accession numbers for cryptogonimid species sequences newly generated for this study.

Codes used for each cryptogonimid sequenced are as shown in the terminal taxa names of Figure 2 and Supplementary figures S3-4. 
Table 1. GenBank accession numbers for cryptogonimid species sequences newly generated for this study. Codes used for each cryptogonimid sequenced are as shown in the terminal taxa names of Figure 1 and Supplementary Figures S2-4.

\begin{tabular}{|c|c|c|c|c|}
\hline \multirow[b]{2}{*}{ Name } & \multirow[b]{2}{*}{ Code } & \multirow[b]{2}{*}{ Life cycle stage } & \multicolumn{2}{|c|}{ GenBank Accession } \\
\hline & & & $28 \mathrm{~S}$ & ITS1-5.8S-ITS2 \\
\hline Timoniella cf. loossi & 1 & Metacercarie & MG383502 & MG383515 \\
\hline Timoniella cf. loossi & 2 & Metacercarie & MG383503 & MG383516 \\
\hline Timoniella cf. loossi & 3 & Metacercarie & MG383504 & MG383517 \\
\hline Timoniella cf. loossi & 4 & Metacercarie & MG383505 & MG383518 \\
\hline Timoniella cf. loossi & 5 & Metacercarie & MG383506 & MG383519 \\
\hline Acanthostomum cf. & & & MG383496 & MG383509 \\
\hline americanum & $1 \mathrm{c}$ & Cercarie & & \\
\hline Acanthostomum cf. & & & MG383497 & MG383510 \\
\hline americanum & $2 \mathrm{c}$ & Cercarie & & \\
\hline Acanthostomum cf. & & & MG383498 & MG383511 \\
\hline americanum & $3 \mathrm{c}$ & Cercarie & & \\
\hline Acanthostomum cf. & & & MG383499 & MG383512 \\
\hline americanum & $1 \mathrm{~m}$ & Metacercarie & & \\
\hline Acanthostomum cf. & & & MG383500 & MG383513 \\
\hline americanum & $2 \mathrm{~m}$ & Metacercarie & & \\
\hline Acanthostomum cf. & & & MG383501 & MG383514 \\
\hline americanum & $3 \mathrm{~m}$ & Metacercarie & & \\
\hline Oligogonotylus mayae & & Adult & MG383507 & MG383520 \\
\hline Crassicutis cichlasomae & & Adult & MG383508 & MG383521 \\
\hline
\end{tabular}

